\title{
Karakteristik dan Perilaku Caregiver Lansia dengan Comorbid dalam Pencegahan Infeksi Covid-19
}

\author{
Irwadi*, Arina Widya Murni, Elvi Oktarina \\ Fakultas Keperawatan Universitas Andalas \\ Limau Manis, Kec. Pauh, Kota Padang, Sumatra Barat, Indonesia 25163 \\ *Correspondence email: irwadirsilampal@gmail.com
}

\begin{abstract}
Abstrak. Pemberian pendidikan dalam pencegahan infeksi COVID-19 merupakan salah satu upaya untuk mengurangi angka kesakitan dan kematian pada lansia. Namun setelah dilakukan pendidikan kesehatan pada caregiver lansia angka kejadian COVID-19 masih tinggi. Penelitian ini merupakan penelitian deskriptif yang bertujuan untuk mengeksplorasi karakteristik, dan perilaku caregiver lansia dalam pencegahan infeksi COVID-19. Hal ini dilakukan untuk dapat merencanakan pemberian intervensi lebih lanjut pada caregiver lansia. Tehnik pengambilan sampel menggunakan metode non probability dengan tehnik total sampling yang berjumlah 76 responden. Instrumen penelitian menggunakan KAP (Knowledge, Attitudes, and Practices) dengan jumlah soal 32 pertanyaan, cronbach alpha pengetahuan (0.834), sikap (0.791) dan tindakan (0.828). Analisa data menggunakan analisis univariat. Karakteristik responden pada usia 18-40 tahun (86,8\%), Jenis kelamin terbanyak perempuan (94.7\%), pendidikan terbanyak SMA $(63,1 \%)$ dan hubungan caregiver dengan lansia adalah $(84,2 \%)$. Nilai mean pengetahuan 7,55 , sikap dengan nilai mean 26,24 , dan tindakan dengan nilai mean 27,21 . Berdasarkan kesimpulan hasil penelitian perilaku caregiver lansia denagan comorbid dalam pencegahan infeksi COVID-19 terkait dengan faktor- faktor resiko terinfeksinya COVID-19 belum adekuat sehingga dapat menyebabkan lansia mempunyai resiko terinfeksi COVID-19.
\end{abstract}

Kata kunci: karakteristik Caregiver; perilaku pencegahan infeksi COVID-19

Abstract. Providing education in the prevention of COVID-19 infection is an effort to reduce morbidity and mortality in the elderly. However, after health education was carried out on elderly caregivers, the incidence of COVID-19 was still high. This research is a descriptive study that aims to explore the characteristics and behavior of elderly caregivers in preventing COVID-19 infection. This is done to be able to plan the provision of further interventions to the elderly caregiver. The sampling technique used non-probability methods with a total sampling technique totaling 76 respondents. The research instrument used KAP (Knowledge, Attitudes, and Practices) with a total of 32 questions, Cronbach alpha knowledge (0.834), attitude (0.791), and action (0.828). Data analysis using univariate analysis. Characteristics of respondents at the age of 18-40 years (86.8\%), the most gender is female (94.7\%), most education is high school (63.1\%) and the relationship between caregiver and the elderly is (84.2\%). The mean value of knowledge is 7.55, attitude is with a mean value of 26.24, and action is with a mean value of 27.21 . Based on the conclusion, the results of research on the behavior of elderly caregivers with comorbidities in the prevention of COVID-19 infection are related to the inadequate risk factors for infection with COVID-19 so that it can cause the elderly to have the risk of being infected with COVID-19.

Keywords: Caregiver characteristics; COVID-19 infection prevention behavior

\section{PENDAHULUAN}

Peningkatan prevalensi Coronavirus Disease COVID-19 menjadi permasalahan kesehatan dunia saat ini yang menyebabkan angka kematian tinggi, salah satu kelompok yang rentan mudah terinfeksi virus serta angka kematian lebih tinggi pada orang berusia $\geq 60$ tahun dan mempunyai lebih dua penyakit kronis, kondisi ini menurut Sanyaolu \& Okorie, (2020) disebut comorbid, kondisi comorbid ini akan semakin berat jika terinfeksi COVID-19 (WHO, 2020). Di Indonesia penyebaran COVID-19 dimulai awal 2 Maret 2020 pemerintah mengumumkan dua kasus pasien positif COVID-19. Saat ini Indonesia menduduki urutan ke-23 didunia dan ke-2 diasia tenggara. Jumlah terkonfirmasi kasus COVID-19 pada usia >60 tahun pada bulan Maret sampai September berjumlah 29.011 jiwa dan persentase kematian sebesar 41,27\% (Covid19.go.id, 2020).

Lansia rentan untuk terpapar COVID-19 dan meyebabkan angka kematian tertinggi ini dikarenakan penurunan fungsi organ-organ pada seluruh sistem tubuh termasuk imun akibat peroses penuaan (Ilpaj \& Nurwati, 2020) Faktor lain yang mempengaruhi kesehatan lansia disebabkan oleh kurangnya pengetahuan yang memadai oleh caregiver sehingga menyebabkan kerugian yang tidak disengaja pada orang yang mereka cintai, dan mungkin diri mereka sendiri (Bassah, Ubenoh, \& Palle, 2018). Penyebab tingginya kasus COVID-19 akibat kurangnya pemahaman dan keperdulian pengasuh, masyarakat, komonitas dan keluarga tentang penerapan pencegahan COVID-19 untuk meningkatkan keperdulian mereka tentang kesehatan dan kesadaran resiko pada lansia (Sun, Yang, Zhang, \& Cheng, 2020)

Pentingnya caregiver lansia untuk mendapatkan pendidikan agar dapat meningkatkan pengetahuan dalam merawat lansia (Bassah et al., 2018). Dalam penelitian yang dilakukan oleh Blevins, (2020) menyebutkan bahwa pendidikan bagi caregiver sangatlah penting, sehingga membutuhkan petunjuk bagaimana cara 
merawat anggota keluarga dan cara pencegahan diri agar tidak tertular virus.

Dengan meningkatnya penyebaran COVID-19 terutama pada kelompok lansia sehingga Caregiver dapat memberikan informasi kepada orang tua tentang cara mengisolasi diri di rumah, menjaga jarak minimal 1 meter dari anggota keluarga lain, mencuci tangan. Selain itu yang dapat dilakukan caregiver lansia untuk mencegah infeksi antara lain dengan membersihkan dan disinfektan tempat yang sering digunakan seperti sakelar lampu, telepon, pegangan pintu serta mengunakan masker (WHO, 2020). dengan adanya caregiver sangatlah pentinng dalam mencegah penularan COVID19 pada lansia dengan menerapkan dan menganjarkan kebiasaan cuci tangan, jaga jarak, penggunaan masker, olahraga, aktivitas istirahat yang benar, memenuhi nutrisi yang baik dan seimbang serta aktif dalam menjaga pola keharmonisan antar anggota keluarga (Abidin et al., 2020)

Dalam masa COVID-19 ini menjadi tantangan bagi pelayanan kesehetan selain harus menerapkan sosial distancing dan juga tetap melakukan pemberian bimbingan dan melatih untuk memberikan pendidikan kesehatan dengan baik, mengingat pendidikan kesehatan sangat berperan penting tidak hanya pencegahan COVID-19 tetapi juga pencegahan komplikasinya. (Hughes, Stallard, \& West, 2020). Menangapi fenomena ini, tenaga kesehatan harus memikirkan strategi lain dalam menyampaikan pendidikan untuk meningkatkan pengetahuan, strategi yang dapat digunakan adalah dengan memanfaatkan media sosial yang sangat berkembang pesat didunia saat ini (Sampurno, Kusumandyoko, \& Islam, 2020).

Media sosial ini dapat dijadikan sebagai alat untuk meningkatkan pengetahuan dibidang kesehatan, era teknologi memiliki peran besar dalam pencapaian informasi kesehatan dalam pencegahan penyakit menular atau pun tidak menular, promosi kesehatan, meningkatkan pelayanan kesehatan untuk memanfaatkan media sosial sebagai alternatif utama dalam jejaring professional (Mohammad, et al., 2019) Keuntungan melakukan pendidikan dengan menggunakan media sosial dalam pendidikan kesehatan dapat menanggulangi batas waktu dan jarak, lebih praktis dan metode instruksional baru sesuai dengan perkembangan zaman yang bisa digunakan dalam penyampaian pembelajaran (M. Z. Latif, Hussain, \& Atif, 2019).

Media edukasi yang dapat diberikan melalui sosial media berupa audiovisual bisa memfasilitasi dan mengakomodasi pengetahuan serta keterampilan individu (S. Latif, Ahmed, Amin, Syed, \& Ahmede, 2016). Penelitian yang dilakukan (Bara et al., 2020) menyebutkan edukasi yang dilakukan secara online efektif dalam meningkatkan pengetahuan masyarakat dalam pencegahan COVID-19 dengan menggunakan media audiovisual (video). Menurut Susilowati (2016) jika informasi diberikan secara audiovisual kemampuan menginggat setelah 3 jam yaitu $85 \%$ dan setelah 3 hari $65 \%$.

Studi pendahuluan yang dilakukan oleh peneliti di Rumah Sakit Islam Siti Khadijah Palembang. didapatkan bahwa program dalam upaya pencegahan penularan COVID-19 sudah dilaksanakan dan diberikan edukasi tentang pencegahan dan penularan pada pengunjung yang datang kerumah sakit, oleh tim promkes rumah sakit dengan media leafleat dan facebook. Wawancara yang dilakukan pada 12 caregiver lansia dengan comorbid yang datang ke Rumah Sakit, 12 caregiver mengatakan jarang mengakses informasi tentang kesehatan dan pencegahan virus corona. Hasil wawancara dan observasi didapatkan 8 dari 12 caregiver lansia tidak menggunakan baju panjang, dan tidak menggunakan alas kaki yang tertutup, serta tidak mencuci pakaian dan mandi saat tiba dirumah. 6 dari 12 caregiver lansia masih membiarkan lansia keluar rumah dan berkujung ketempat keramaian seperti pasar tradisional, dan membantu berjualan serta masih ada lansia yang datang sendiri untuk berobat dan mengambil obat rutinnya ke rumah sakit. Berdasarkan latar belakang di atas maka peneliti tertarik untuk melakukan penelitian mengenai gambaran karakteristik pengetahuan, sikap dan tindakan dalam pencegahan infeksi COVID-19 pada caregiver lansia di Kota Palembang, karena wilayah kerja puskesmas Gandus. Penelitian ini merupakan penelitian deskriptif cross sectional yang bertujuan untuk mengeksplorasi karakteristik, dan perilaku caregiver lansia dengan comorbid dalam pencegahan infeksi COVID-19.

\section{METODE}

Penelitian ini merupakan penelitian kuantitatif dengan desain penelitian deskriptif menggunakan teknik pengambilan sampel total sampling, yaitu caregiver lansia yang datang ke Rumah Sakit Islam Siti Khadijah Palembang 2021. Kriteria inklusi pada penelitian ini, yaitu Usia Responden 18 - 55 tahun, Keluarga yang memiliki lansia dengan comorbid ( penyakit utama DM, Hipertensi dan penyakit jantung) dengan penyerta, Caregiver informal (Suami/istri, anak, menantu, teman dan tetangga) Caregiver yang merawat lansia $>8$ jam / hari dan bersedia menjadi responden.

Instrumen penelitian adalah lembar kuesioner KAP (Knowledge, Attitudes, and Practices) yang terdiri dari dua bagian yaitu data demografi, pengetahuan, sikap dan tindakan ibu tentang pencegahan pneumonia berjumlah 32 item dengan cronbach alpha pengetahuan (0.834), sikap (0.791) dan tindakan (0.828). Data demografi terdiri dari umur yang dikategorikan dewasa muda (18-40 tahun) dan dewasa tua (> 40 Tahun), jenis kelamin dikatagorikan laki-laki dan perempuan, pndidikan dikatagorikan SD, SMP, SMA, dan PT, dan hubungan dengan lansia di katagorikan anak kandung, menantu, cucu, dan adik/kaka. Pengetahuan (Knowledge) dengan jumlah pertanyaan sebanyak 12 
butir dengan beberapa pilihan jawaban. Jawaban yang paling benar diberi skor 1 , dan jawaban salah diberi skor 0. Kuesioner sikap (Attitudes ) dan tindakan (Practices) dengan jumlah pertanyaan masing-masing sebanyak 10 butir dengan menggunakan skala likert dengan skoring 10-40. Penelitian ini dilaksanakan pada bulan Maret sampai April 2021. Penelitian ini telah mendapatkan surat uji etik yang dikeluarkan Komisi Etik Penelitian Kesehatan RSUP Dr. M. Djamil Padang No. 71/KEPK/2021. Penelitian diawali dengan pengisian lembar informed consent oleh responden, setelah itu mengisi data demografi dan kuesioner pengetahuan, dan tindakan tentang pencegahan infeksi COVID-19.

Data yang telah didapatkan di analisis menggunakan analisis univariat untuk data karakteristik umur, jenis kelamin, pendidikan dan pekerjaan dideskripsikan dengan ukuran persen atau proporsi, sedangkan pengetahuan, sikap dan tindakan dengan nilai mean, minimum, maksimum dan standar deviasi.

\section{HASIL DAN PEMBAHASAN}

Tabel 1 didapatkan jumlah responden pada penelitian ini berjumlah 76 orang. Karakteristik responden meliputi usia, dimana hampir seluruh dari caregiver berusia dewasa muda (18-40 tahun) berjumlah 66 orang $(86,8 \%)$. Jenis kelamin caregiver hampir seluruhnya perempuan berjumlah 72 orang (94.7\%). Pendidikan caregiver sebagian besar berpendidikan SMA/SMK sejumlah 48 orang $(63,1 \%)$. Hubungan caregiver lansia hampir seluruhnya anak berjumlah 65 orang $(84,2 \%)$ orang.

Pada tabel 2 menjelaskan bahwa nilai tertinggi pada pengetahuan adalah 9 dengan rerata pengetahuan 7,55 dan SD (0,950), rerata tindakan 26,16 dan SD $(3,356)$ dan tindakan nilai tertinggi 35 dengan rerata 27,22 dan $\mathrm{SD}(3,772)$.

Tabel 1. Distribusi frekuensi usia caregiver lansia, jenis kelamin, pendidikan dan hubungan caregiver dengan lansia

\begin{tabular}{llcc}
\multicolumn{1}{c}{$(\mathrm{n}=76)$} & & \\
\hline Karakteristik & \multicolumn{1}{c}{ Kategori } & f & \% \\
\hline Usia Caregiver & Dewasa Muda (18-40 tahun) & 66 & 86,8 \\
Jenis kelamin & Dewasa Tua (> 40 Tahun) & 10 & 13,2 \\
& Perempuan & 72 & 94,7 \\
& Laki-laki & 4 & 5,3 \\
Pendidikan & SD & 0 & 0 \\
& SMP & 25 & 32,9 \\
& SMA/SMK & 48 & 63,1 \\
& PT & 3 & 4,0 \\
Hubungan & Anak Kandung & 65 & 84,2 \\
& Menantu & 7 & 9,2 \\
& Cucu & 4 & 5,3 \\
& Adik/Kakak & 1 & 1,3 \\
\hline
\end{tabular}

Tabel 2. Pengetahuan, sikap dan tindakan caregiver dalam pencegahan COVID-19 pada lansia dengan comorbid $(\mathrm{n}=76)$

\begin{tabular}{lccc}
\multicolumn{1}{c}{ Variabel } & Mean & SD & Min-Max \\
\hline Pengetahuan & 7,55 & 0.950 & $6-9$ \\
Sikap & 26,24 & 3,356 & $20-34$ \\
Tindakan & 27,21 & 3.772 & $20-35$ \\
\hline
\end{tabular}

\section{Pembahasan}

Hasil penelitian didapatkan bahwa usia caregiver hampir seluruhnya berusia pada golongan dewasa muda (18-40 tahun) yaitu sebanyak 66 orang (86,8\%). Putri (2018) menyatakan bahwa Umur sangat berkaitan dengan kedewasaan seseorang, umur semakin bertambah akan meningkatkan kebijakan kemampuan seseorang untuk mengambil keputusan, berpikir rasional, mengendalikan emosi dan bertoleransi terhadap pandangan orang lain.

Menurut Mubarak (2012) saat usia bertambah dewasa maka perubahan akan terjadi pada fisik dan psikologis, pada fisik terjadi disebabkan mematangnya fungsi dari organ akan tubuh, sedangkan pada psikologis mebuat individu memiliki pola berpikir yang lebih matang dan dewasa sehingga mudah dalam menerima dan memberikan informasi.

Jenis kelamin caregiver lansia adalah perempuan sebanyak 72 orang $(94,75 \%)$. Data penelitian ini didukung oleh penelitian Ariska et al (2020) menyebutkan bahwa sebagian besar caregiver adalah perempuan sebanyak $(79,5 \%)$ ini dipengaruhi oleh beberapa faktor antaralain norma dan budaya yang berlaku seperti di indonesia tugas perempuan adalah mengurus rumah tangga dan merawat anggota keluarga sedangkan lali-laki mencari nafkah sehingga perempuan banyak berperan dalam merawat orang yang sakit. Caregiver banyak didominasi perempuan disebabkan perempuan memiliki kemampuan fisik, keterampilan, kebersihan, mengendalikan emosi, peran sosial, simpati, empati, sabar dan memiliki tingkat adaftasi yang tinggi jika dibanding laki-laki ketika sedang merawat lansia yang sedang sakit (Rita Hadi Widiastuti, 2019)

Pendidikan caregiver lansia berpendidikan SMA sebanyak 48 orang $(63.15 \%)$. Data penelitian ini didukung oleh Rita Hadi Widiastuti (2019) sebagian besar caregiver lansia berpendidikan SMA/SMK (68.3\%). Tingkat pendidkan caregiver sangat mempengaruhi bagaimana seseorang merawat lansia untuk mencari penyebab serta solusi kita terjadi masalah dalam merawat lansia. Menurut (Sari, Said, \& Malasari, 2016) dengan tingkat pendidikan yang semakin tinggi akan bertindak lebih rasional dan mudah menerima gagasan baru dan bersifat terbuka dalam menirima informasi tentang kesehatan dalam merawat anggota keluarga yang sedang sakit. Selain itu tingkat pendidikan caregiver salah satu faktor yang secara tidak langsung dapat mempengaruhi kesehatan dalam massa pandemik ini, dengan memiliki tingkat pendidikan yang tinggi sehingga seseorang dapat memahami tahap-tahap 
pencegahan COVID-19 baik terhadap dirisendiri, keluarga dan orang yang lanjut usia (Ellya, 2020).

Hasil penelitian yang dilakukan pada 76 responden kelompok intervensi dan kelompok kontrol sebagian besar hubungan caregiver yang merawat lansia adalah anak sebanyak 65 orang $(84.2 \%)$. Data penelitian ini didukung oleh Kartika et al (2019) mejelaskan orang yang berperan sebagai caregiver lansia adalah anak $(73,9 \%)$. Anak memiliki tanggung jawab terhadap orang tua untuk memberikan kasih sayang, perhatian, perlindungan dan memenuhi kebutuhan Lansia serta merawat jika lansia mengalami sakit. Peran keluarga sebagai caregiver lansia juga dipengaruhi oleh pandangan dalam masayarakat dan agama bahwa anak wajib untuk meberikan kasih sayang seperti mereka dapatkan sewaktu masih kecil hal ini menimbulkan perasaan tanggung jawab untuk merawat lansia dan meberikan nafkah bagi keluarga (Siti Nur Alfiaturrohmah, Rina Anggraeni, 2018). Keluarga merupakan pendukung yang paling utama bagi lansia dalam mempertahankan kesehatannya, peran keluarga dalam hal ini merawat serta menjaga lansia, mempertahankan dan meninggkatkan kesehatan, memberikan dukungan dan mepasilitasi kebutuhan lansia (Amri, 2019).

Berdasarkan pengolahan data kuesioner pengetahuan, didapatkan rerata pengetahuan adalah 7,55. Nilai rerata ini menunjukkan bahwa lebih dari sebagian responden telah memiliki pengetahuan baik tentang pencegahan infeksi COVID-19 pada lansia. Walaupun ada hal-hal yang penting dari pengetahuan tentang COVID-19 yang belum reponden ketahui. Hal tersebut dibuktikan dari analisis kuesioner yang peneliti lakukan terkait langkah etika batuk dan bersin yang benar, pencegahan infeksi COVID-19 yang dilakukan dilingkungn rumah.

Hasil analisis tersebut menjelaskan bahwa pengetahuan caregiver mengenai pencegahan COVID19 pada lansia belum adekuat. Pencegahan COVID-19 merupakan tindakan yang harus dilakukan oleh keluarga agar anggota kelurga yang berisiko terhindari dari infeksi COVID-19. Pengetahuan merupakan hasil dari tahu seseorang setelah melakukan pengindraan pada objek tertentu dengan melihat, mendengar dan merasakan dengan sendiri, sebagian besar pengetahuan didapat dari melihat dan mendengar (Notoatmodjo, 2012). Faktor lain yang mempengaruhi pengetahuan sesorang yaitu dari segi umur, tingkat pendidikan, pekerjaan, pengalaman individu, dan informasi yang diterima (Nurmala, 2018). Upaya yang dilakukan adalah dengan meningkatkan kesadaran dan pengetahuan serta kedisiplinan seluruh anggota keluarga terhadap hal-hal yang dapat meningkatkan faktor resiko terjadi COVID19 (Santika, 2020)

Analisis kuesioner sikap didapatkan rerata adalah 26,24. Nilai rerata ini menunjukkan bahwa lebih dari sebagian caregiver telah memiliki sikap positif tentang pencegahan infeksi COVID-19 pada lansia. Hasil tersebut menjelaskan bahwa sikap caregiver mengenai pencegahan infeksi COVID-19 pada lansia belum seluruhnya bersikap positif. Pada item peryataan sikap mengenai semua lansia yang terinfeksi COVID-19 merupakan orang yang melanggar protokol kesehatan dijawab dengan nilai paling rendah oleh responden. Berdasarkan hasil wawancara bahwa responden tidak mengetahui bahwa penularan COVID-19 tidak hanya dari kontak erat dengan penderita, tidak cuci tanggan dan tidak memakai masker, tetapi dapat ditularkan melalui pakaian yang digunaakan saat keluar rumah yang tidak langsung dicuci dan tidak mandi, serta jarang membersihkan tempat yang sering digunakan lansia dengan menggunakan cairan desinfektan, sehingga mereka sanggat setuju bahwa lansia yang terinfeksi COVID-19 merupakan melanggar protokol kesehatan.

Sikap suatu reaksi atau respon yang masih tertutup dari seseorang terhadap stimulus yang diterima (Maulana, 2013). Menurut Notoatmodjo (2012) sikap terdiri dari bebrapa tingkatan, seperti menerima (receving), merespon (responding), menghargai (valuing), dan bertanggung jawab (responsible). Tahapan membentuk sikap akan mengubah sikap seseorang dari negatif menjadi positif. Peningkatan sikap caregiver lansia sesuai yang dikemukana oleh Lawrence Green (1980) dalam Adventus, I Made Merta Jaya (2019) yang menjelaskan bahwa dengan memberikan peendidikan kesehatan dapat merubah faktor predisposisi, salah satu faktor predisposisi adalah sikap seseorang.

Berdasarkan kuesioner tindakan tentang pencegahan pneumonia, didapat nilai rerata adalah 27,21. Nilai tersebut menggambarkan responden masih belum memiliki tindakan yang positif dalam pencegahan infeksi COVID-19 pada lansia. Hasil analisis kuesioner didapat lebih dari sebagian responden memiliki tindakan negative tentang pencegahan infeksi COVID-19 seperti tidak menggunakan baju lengan panjang, celana panjang dan alas kaki tertutup saat keluar rumah, tidak mencuci pakain dan mandi langsung saat tiba dirumah, tidak melakukan pemantau kesehatan lansia secara mandiri dirumah. Dengan kata lain, responden belum melakukan tindakan positif pencegahan infeksi COVID-19 pada lansia dapat dikaitkan dengan kurangnya pengetahuan dan sikap positif dalam pencegahan infeksi COVID-19. Meningkatkan pengetahuan keluarga tentang COVID-19 sangatlah penting agar tidak menyebabkan penambahan kasus, sehingga bisa memahami tentang penyakit, cara pencegahan, komplikasi yang terjadi serta pengobatan sehingga dapat melindungi anggota keluarga yang memiliki comorbid upaya yang dilakukan dengan memberikan pendidikan kesehatan (Fadilah, 2020) 


\section{SIMPULAN}

Perilaku caregiver dalam pencegahan infeksi COVID-19 pada lansia terkait dengan faktor-faktor resiko penyebab terjadinya COVID-19 belum adekuat, sehingga dapat menyebabkan lansia mempunyai resiko terjadinya COVID-19. Salah satu upaya pencegahan COVID-19 pada lansia yaitu dengan meningkatkan pengetahuan, sikap, dan tindakan caregiver dalam pencegahan infeksi COVID-19 dengan memberikan pendidikan kesehatan.

\section{DAFTAR PUSTAKA}

Abidin, A. Z., Julianto, E. K., Insan, S., \& Husada, C. (2020). Pencegahan Penularan COVID19 Bagi Lansia Di Desa. 1-9.

Adventus, I Made Merta Jaya, D. M. (2019). Buku Ajar Promosi Kesehatan. Jakarta.

Amri, L. F. (2019). Efektifitas Edukasi Pada Caregiver Tentang Pengetahuan Kejadian Pengabaian Lansia Effectiveness of Education on Knowledge About The Event Negligence Caregiver Elderly.https://doi.org/https://doi.org/10.33757/jik .v3i2.241

Ariska, Y. N., Handayani, P. A., \& Hartati, E. (2020). Faktor yang Berhubungan dengan Beban Caregiver dalam Merawat Keluarga yang Mengalami Stroke. Journal of Holistic Nursing and Health Science, 3(1), 52-63.

Bara, S., Mahmudah, R., Ruslin, Aba, L., Nggawu, L. O., Syahbudin, ... Hasyim, M. S. (2020). Efektivitas Pemberian Edukasi secara Online melalui Media Video dan Leaflet terhadap Tingkat Pengetahuan Pencegahan Covid-19 di Kota Baubau. Jurnal Farmasi Galenika (Galenika Journal of Pharmacy) .https://doi.org/10.22487/j24428744.2020.v6.i2.15 253

Bassah, N., Ubenoh, U. S., \& Palle, J. N. (2018). An Exploratory Study of the Knowledge and Practices of Family Caregivers in the Care of the Elderly at Home in the Buea Health District, Cameroon. Journal of Gerontology \& Geriatric Research, 7(3), 3-7. https://doi.org/10.4172/21677182.1000473

Blevins, S. (2020). COVID-19 Education for Caregivers. Retrieved september 29, 2020 From https://www.proquest.com.

Covid19.go.id. (2020). Analisis Data COVID-19 Indonesia Updet Per 27 September 2020. Retrieved Septemer 30, 2020. From https://covid19.go.id.

Ellya. (2020). Peranan Keluarga Dalam Menghadapi Pandemi covid-19 di Indonesia. In PT Raja Grafindo Persada. Retrieved from https://www.researchgate.net/publication/3442607 47

Fadilah, M. (2020). Analysis Of Family Knowledge
Against Comorbid Diseases In The Covid-19 Pandemic Era Through Online Seminars. Jurnal Ilmu Kesehatan, 9(1), 86-93.

Hughes, B. A., Stallard, J., \& West, C. C. (2020). The use of Whatsapp $\mathbb{R}$ as a way to deliver plastic surgery teaching during the COVID-19 pandemic. Journal of Plastic, Reconstructive and Aesthetic Surgery, $1-2$. https://doi.org/10.1016/j.bjps.2020.05.034

Ilpaj, S. M., \& Nurwati, N. (2020). Analisis Pengaruh Tingkat Kematian Akibat Covid-19. Jurnal Pekerjaan Sosial, 3(1), 16-28.

Kartika, A. W., Choiriyah, M., Kristianingrum, N. D., Noviyanti, L. W., \& Fatma, E. P. L. (2019). Pelatihan Tugas Perawatan Kesehatan Keluarga Caregiver Lansia dalam Pogram RURAL (Rumah Ramah Lansia). Jurnal Pengabdian Kepada Masyarakat (Indonesian Journal of Community Engagement), 5(3), 448. https://doi.org/10.22146/jpkm.45139

Latif, M. Z., Hussain, I., \& Atif, M. (2019). Use of Smart Phones and Social Media in Medical Education: Trends, Advantages, Challenges and Barriers. 27(2), 133138.https://doi.org/10.5455/aim.2019.27.133-138

Latif, S., Ahmed, I., Amin, M. S., Syed, I., \& Ahmede, N. (2016). Exploring the potential impact of health promotion videos as a low cost intervention to reduce health inequalities: A pilot before and after study on Bangladeshis in Inner-city London. London Journal of Primary Care, 8(4), 66-71. https://doi.org/10.1080/17571472.2016.1208382

Mohammad, Shariful, S., Tabassum, R., Liu, Y., Chen, S., Redfern, J., Kim, S. Y., Chow, C. K. (2019). The role of social media in preventing and managing non-communicable diseases in low-andmiddle income countries: Hope or hype? Health Policy and Technology, 8(1), 96101.https://doi.org/10.1016/j.hlpt.2019.01.001

Notoatmodjo, S. (2012). Promosi Kesehatan dan Prilaku Kesehatan. Jakarta: Rineka Cipta.

Nurmala, I. (2018). Promosi Kesehatan. Surabaya: Arlanga.

Putri, A. F. (2018). Pentingnya Orang Dewasa Awal Menyelesaikan Tugas Perkembangannya. SCHOULID: Indonesian Journal of School Counseling.https://doi.org/10.23916/08430011

Rita Hadi Widiastuti. (2019). BEBAN DAN KOPING CAREGIVER LANSIA DEMENSIA DI PANTI WREDHA. Jurnal Ilmu Keperawatan Komunitas, 2(1), 8-18.

Sampurno, M. B. T., Kusumandyoko, T. C., \& Islam, M. A. (2020). Budaya Media Sosial, Edukasi Masyarakat, dan Pandemi COVID-19. SALAM: Jurnal Sosial Dan Budaya Syar-I, 7(5). https://doi.org/10.15408/sjsbs.v7i5.15210 
Irwadi, Arina Widya Murni dan Elvi Oktarina, Karakteristik dan Perilaku Caregiver Lansia dengan Comorbid dalam Pencegahan Infeksi Covid-19

Santika, I. G. N. (2020). Optimalisasi Peran Keluarga Dalam Menghadapi Persoalan Covid- 19: Sebuah Kajian Literatur. https://doi.org/http://dx.doi.org/10.23887/jiis.v6i2. 28437

Sanyaolu, A. O., \& Okorie, C. (2020). Komorbiditas dan Dampaknya pada Penderita COVID-19. https://doi.org/10.1007/s42399-020 00363-4

Sari, M. M., Said, S., \& Malasari, S. (2016). Training of caregiver towards family independence level in caring for elderly with hypertension. Indonesian Contemporary Nursing Journal, 1(1), 17.https://doi.org/https://doi.org/10.20956/icon.v1i 1.3218

Siti Nur Alfiaturrohmah, Rina Anggraeni, R. P. J. (2018). Hubungan Peran Family Caregiver Terhadap Pemenuhan Personal Relationship Between the Role of Family Caregiver on the Personal Hygiene Fulfillment in Elderly. Jurnal Keperawatan Sekolah Tinggi Ilmu Kesehatan Kendal, 10(2), 143-148.

Sun, Z., Yang, B., Zhang, R., \& Cheng, X. (2020). Influencing factors of understanding covid-19 risks and coping behaviors among the elderly population. International Journal of Environmental Research and Public Health, 17(16), 1-16. https://doi.org/10.3390/ijerph17165889

Susilowati, D. (2016). Promosi Kesehatan. Jakarta Selatan: Kementrian Kesehatan Republik Indonesia.

WHO. (2020a). Coronavirus Disease - 2019 (COVID19) Situation Report-41. Retrieved march 29, 2020 From https://www.who.int. ChemRxiv, 2019. https://doi.org/10.26434/chemrxiv.12037416.v1

WHO. (2020b). Guidance on COVID-19 for the care of older people and people living in long-term care facilities, other non-acute care facilities and home care, Retrieved Agustus 29, 2020 From https://iris.wpro.who.int/handle. 